\title{
THE GLUCOSE TOLERANCE TEST
}

By Joyce D. Baird, M.A., M.B.Ch.B., and Leslie J. P. Duncan, B.Sc., M.B.Ch.B., M.R.C.P.E.

From the Department of Therapeutics, University of Edinburgh

\section{Introduction}

The rise and fall of the blood glucose concentration following oral or intravenous administration of glucose - ' the glucose tolerance curve'has long been widely used both clinically and experimentally in animals and man as an index of the efficiency of the mechanisms regulating the concentration of glucose in the blood. Many of the published data are conflicting, and the variation in method ${ }^{95}$ employed by different workers makes comparison of results impossible. Even when the same procedure has been used in apparently similar circumstances, different results have often been obtained. Lack of general agreement about either the evaluation or the interpretation of the different blood glucose curves resulting from any of the various techniques employed increases the confusion. Moreover, it is insufficiently recognized that glucose tolerance tests can provide only limited information about carbohydrate metabolism, and unwarranted deductions have all too frequently been made from them.

This situation is due to several factors:

\section{(I) Failure to standardize the conditions of the} test.

The diverse disorders in which alteration of the glucose tolerance curve has been reported emphasize the numerous factors which may influence it. However, it has not been generally appreciated that the configuration of the curve may be modified by exogenous factors unrelated to the endogenous control of carbohydrate metabolism. These include: state of nutrition, $21,28,43$ antecedent diet, particularly carbohydrate content, but possibly also protein content, ${ }^{21,} 51,52,53,54,64,81,83,122,123,127,128,132$ preceding exercise, ${ }^{18,29,75}$ and prolonged inactivity, ${ }^{11}$ fear or other emotion, ${ }^{55,} 91,109$ posture during the test, ${ }^{97}$ interference with the blood supply to muscle masses by a simple mechanical procedure such as elevation of the legs, ${ }^{16}$ the strength of the glucose solution, and the dose administered, ${ }^{46,} 94$ the site of sampling, i.e. the use of capillary or venous blood, ${ }^{94}$ the use of a tourni- quet in obtaining blood samples, ${ }^{78}$ the frequency $\overrightarrow{\vec{\omega}}$ of blood sampling, ${ }^{39}$ fever, or even the mildest $\stackrel{\omega}{\sigma}$ infection such as a head cold, ${ }^{73}, 109,124,128$ the $\bar{O}$ method used for the blood glucose estimation, 3 and the accuracy of the procedure, ${ }^{93,} 94$ ingestion of certain drugs, for example, large doses of sedatives and hypnotics, ${ }^{60}, 89$ various anaes- $C$ thetics, ${ }^{33}$ steroids ${ }^{62}$ and salicylates. ${ }^{106}$

Glucose tolerance can be defined as "the capacity to dispose of administered glucose under 을 standard conditions.' ${ }^{126}$ Although the influence of the above factors on the glucose tolerance curve $z$ is well-documented, they have usually been ignored. This has led Soskin ${ }^{\mathbf{1 2 1}}$ to state, with some $\overrightarrow{0}$ exaggeration, that 'the oral dextrose tolerance tes as ordinarily used and interpreted is practicals. worthless.' Standardization and control of these factors is essential, no matter what procedure is used in carrying out the glucose tolerance test, to obtain results of any value. It is possible that other unknown factors may also influence the test.

\section{(2) Inadequate control groups.}

Subjects selected for control observations have often been too few to establish the limits of normal tolerance; have only rarely been matched for age, ${ }^{116}$ sex, weight, ${ }^{99}$ parity, ${ }^{80}$ previous diet or activity; have often been receiving drugs or have been suffering from a condition which may affect carbohydrate metabolism, such as hepatic disease, ${ }^{2,120}$ fever, inflammation or any form of stress, ${ }^{2,}, 25,128$ obvious endocrine disorders, ${ }^{133}$ neoplastic disease, ${ }^{88}$ uraemia, ${ }^{2,101}$ hypertension, ${ }^{50} \frac{\mathrm{D}}{\mathrm{O}}$ arthritis, ${ }^{100}$ schizophrenia, manic-depressive or involutional psychoses, ${ }^{37}, 48,49$ disseminated scle- $N$ rosis, ${ }^{48,}{ }^{49}$ Paget's disease, ${ }^{92}$ phaeochromocytoma, ${ }^{36}$ N gout, ${ }^{135}$ chronic alcoholism, ${ }^{14}$ periodic paralysis, ${ }^{82}$ N coronary thrombosis, ${ }^{112}$ gastric or duodenal ulcer, ${ }^{111} \underset{\sigma}{\omega}$ or steatorrhoea; 37 a family history of diabetes mellitus has only rarely been carefully excluded ${ }^{31} \stackrel{0}{\subseteq}$ along with any features of the " prediabetic state.'65

(3) Faulty concepts of glucose tolerance.

Claude Bernard ${ }^{10}$ keenly appreciated the dynamic balance involved in the maintenance of a 
constant ' milieu interior.' He stated clearly that the normal blood glucose level represented a precise equilibrium between the rates of glucose formation by the liver and of glucose assimilation by the tissues.

Blumenthal, ${ }^{12} 50$ years ago, again emphasized that the true concept of glucose tolerance is not static but dynamic, when he defined it as "the maximum quantity which can be dealt with in each unit of time without disturbing the homeostasis of the body.' As Ross ${ }^{109}$ points out, 'this fundamental idea makes it necessary to control the rate of entry into the circulation, and such control obviously demands intravenous administration.'

Since the discovery of insulin the concept of dynamic balance has been virtually ignored, and the general tendency, with few exceptions, has been to interpret the results of glucose tolerance tests almost exclusively in terms of tissue assimilation of glucose, and to administer the glucose load by mouth.

\section{The Oral Glucose Tolerance Test The Absorption of Glucose}

Most workers have administered the glucose load by mouth in the belief that the rate of absorption of glucose was 'independent of both the absolute amount and the concentration of glucose present in the intestine,' and that sugars were absorbed ' at a constant rate up to the point of their disappearance from the intestine,' the actual rate being determined by the structure of the glucose molecule. ${ }^{22}$ However, this belief, that the absorption of glucose was comparable to its continuous infusion at a constant rate, was denied in 1933 by Mackay and Bergman ${ }^{84}$ who reported that absorption was markedly influenced by the concentration of the administered solution.

Many papers are to be found supporting each of these concepts, the conflicting data being due to the variety of techniques used to study the absorption of glucose, all of which have certain limitations.

This problem has recently been investigated by a technique allowing the simultaneous observation of gastric emptying, intestinal transit, and absorption of test substances from the gastro-intestinal tract in the intact, conscious animal, 107,108 and it has been shown conclusively that: (a) glucose is absorbed from the stomach, the proportion varying with the total glucose load. The absorptive capacity of the stomach is, however, readily saturated, and rarely exceeds $100 \mathrm{mg}$. per hour, so that at high-glucose loads the proportion of glucose absorbed by the stomach will be small, and gastric emptying is the most important single determinant of total glucose absorption per unit of time. (b) The rate of emptying varies greatly among normal animals ${ }^{33}$ and is affected markedly by the concentration of the administered solus tion.33, 104 Gastric emptying becomes progressively delayed as the concentration of the introduced solutions is increased, so that the intestinal glucose load does not increase in proportion to the total glucose load, and glucose is delivered to the small intestine at a rate which is less than its considerable absorptive capacity. Thus, the total glucose absorption in one hour increases very little in relation to the larger load but absorption will continue for a longer, and individually variable period. ${ }^{94}$ Beeler et al. ${ }^{9}$ showed that one hour after giving $100 \mathrm{~g}$. glucose orally to normal and diabetic subjects, 22-68 g. of the administered glucose could be recovered by washing the stomach, without a consistent and significant variation of the glucose tolerance test, and Leonards and Free $^{74}$ found that in normal adult male subjects undergoing the Exton-Rose ${ }^{30}$ test, 38-62 g. glucose could be recovered from the gastric contents after one hour.

The rate of gastric emptying, and thus intestinal absorption of glucose, is, however, influenced by many other factors some of which have already been listed. Prolongation of the pre-experimental fast to 48 hours, ${ }^{33}$ the nausea experienced by some individuals after glucose ingestion, ${ }^{46}$ recumbency or the introduction of gas into the stomach, 98 pregnancy, ${ }^{80}$ and anticholinergic drugs, slow gastric emptying so that a flat glucose tolerance curve may result. In contrast, in conditions where rapid gastric emptying occurs, for example in patients deprived of pyloric control by gastroenterostomy or gastrectomy, ${ }^{29}, 40,136$ glucose delivery to, and absorption from the intestine is unduly rapid, so that the blood glucose concentration very quickly rises to an abnormally high level.

Endocrine factors probably influence intestinal glucose absorption, accounting for the flat glucose tolerance curve seen in hypothyroidism and sometimes in hypoadrenocorticism, and the high curve common in hyperthyroidism and adrenocortical hyperplasia. ${ }^{1,23,110}$ Intestinal hurry, excessive mucus secretion, or diseases like sprue or idiopathic steatorrhoea interfere with glucose absorption so that the tolerance curve will be flat. ${ }^{35,125}$ The response to intravenous glucose may be normal in such cases, ${ }^{32}$ or the diminished absorption may actually lead to a diminished capacity to deal with administered glucose, ${ }^{109}$ thereby confusing the picture still further.

\section{Reproducibility of the Oral Test}

The many factors influencing glucose absorption from the gut have gained wider recognition with the publication from time to time of studies casting 
doubt on the reproducibility of the results of the oral test, even after careful standardization of the diet. 13, 41, 16, 67, 68, 75, 97, 117, 129

Freeman et $a l .37$ concluded that "the variability of the test was so great as to be of little diagnostic value, except in established diabetes mellitus, whether one takes identical points, maximum values, or increases from the control values' even on a standard diet.

Other workers ${ }^{58,129}$ have found that in multiple tests performed on a single individual every type of curve from ' flat' to ' diabetic' was obtained. Mirsky ${ }^{90}$ has stated that anyone can be labelled ' diabetic' if a sufficient number of oral glucose tolerance tests are performed.

On the other hand, Hosters ${ }^{59}$ stated that he obtained consistent results in cases of diabetes mellitus on a fixed diet, and this agrees.with our experience $^{5}$ with diabetic patients under rigidly controlled hospital conditions.

The value of any test in making comparative observations depends on its reproducibility, and it should, therefore, not be influenced by factors unknown, unpredictable, and uncontrollable. The oral glucose tolerance test falls short of these requirements. The use of the intravenous route for administration of the glucose load avoids at least some unknown, as well as many known, factors difficult to control adequately in normal clinical practice, or even under experimental conditions. Such tests are, therefore, being increasingly employed in clinical practice in spite of the larger number of blood samples involved and the difficulties experienced following the intravenous administration of concentrated glucose solutions. ${ }^{26,128}$

\section{The Intravenous Glucose Tolerance Test \\ Method and Interpretation}

Two methods have been mainly employed: the continuous infusion of a weak solution of glucose, ${ }^{56,70}$ or the rapid injection of more concentrated solutions. Although possibly more physiological, the former is too cumbersome for routine clinical practice, and the latter has been used by the majority of workers.

Although the rapid intravenous method has been widely studied over the past three decades, there is still no uniformity of procedure, particularly as regards the 'loading dose' of glucose given, and there is considerable disagreement as to the best method of evaluating the results.

The area under the observed curve, ${ }^{71,109}$ the time taken to reach a definite predetermined value, ${ }^{23}$ and for the blood glucose to regain the fasting value, ${ }^{128}$ and the concentration of the blood glucose at a given interval after the end of the injection, ${ }^{79}$ have all been used to evaluate intravenous glucose tolerance curves.

Several attempts have been made to express the $\frac{\varnothing}{\circ}$ rate of disposal of intravenously administered ${ }_{C}$ glucose as a constant by mathematical analysis of $\Rightarrow$ the rate of fall of the blood glucose level, and the 'glucose assimilation coefficient' (or 'total in-? $\left.\operatorname{dex}^{\prime}\right)^{8,19}$ and the 'increment index '4, 26 have $\frac{\bar{O}}{\bar{*}}$ been suggested as reasonably accurate measures $\frac{\bar{\rho}}{\sigma}$ of glucose disposal rate. Other workers have pro- $\overparen{\unrhd}$ posed evaluation of results in terms of a clearance $\frac{\tilde{\omega}}{\rho}$ of glucose..$^{57,85}$

With one exception ${ }^{56}$ there is general agreement. that under controlled conditions the results ob- $\vec{\omega}$ tained by any one of these techniques are re- $\sigma$ producible and hence can be used for comparative studies. Nevertheless, there is some doubt as to 3 . what is actually occurring, and what is in fact $w$ being measured at different times in the tests, and + the many and varying methods of evaluation reflect $\omega$ the lack of knowledge of the precise mechanisms $\omega$ involved in the disposal of an intravenous glucose ${ }^{\infty}$ load.

Several workers have adjusted the loading dose $\overrightarrow{-}$ of glucose to the subject's weight. This is, however, probably unnecessary since no variation has been observed in the maximum value, the form of $\overrightarrow{0}$ the curve, or the time taken for it to return to the fasting value, which could be correlated witio variation in weight. ${ }^{79}, 128$

Following the rapid intravenous injection of a concentrated glucose solution the blood glucose almost immediately rises to a peak. The maximum $\mathbb{Q}$ height which it attains varies considerably in $\overrightarrow{\vec{F}}$ different subjects, and even in the same subject, 을 when other parts of the curve have not varied. ${ }^{128}$ Since no correlation has been demonstrated between the height of the peak and any of the various indices of evaluation, it may be disregarded, and 3 methods of evaluation 71,109 where the area under $\bar{\sigma}$ the curve is measured are unlikely to have 'any real scientific or even comparative significance. ${ }^{128} \AA$

From the maximum value the blood glucose concentration falls rapidly and smoothly in a concave curve, since the absolute fall is progres- $\rightarrow$ sively retarded. Urinary loss of glucose does not contribute significantly to the fall in blood glucose concentration in normal individuals. Using a loading dose of $25 \mathrm{~g}$. the range is approximately 0 $0-2.8$ g. ${ }^{24}, 76,102,128$ It may, however, be of some $N$ significance in diabetics, but in them the problemo of accurately defining absolute values is less im-o portant. The variation in the curve of the intra- $\frac{\bar{\Phi}}{\Phi}$ venous glucose tolerance test from one individual $\stackrel{\infty}{+}$ to another, and in the different parts of the same 0 curve, is due to a variation in pancreatic and $\bar{D}$ hepatic reaction.

Soskin et al..$^{119}$ have shown (a) that a decreased $\stackrel{\overparen{Q}}{\mathbb{Q}}$ 
hepatic output of glucose is an important factor in glucose tolerance, and have suggested that the effect of insulin is to determine the blood glucose level at which this hepatic reaction occurs, and (b) that the presence of the normal liver is probably essential also for efficient glucose assimilation, since in hepatectomized animals the intact pancreas and musculature are unable to give a normal response. Moreover the pancreas itself may not be absolutely necessary in certain circumstances for normal glucose tolerance, since depancreatizedhypophysectomized animals have a normal tolerance in terms of their ability to dispose of a glucose load.

Despite the fact that several metabolic processes are thus involved, it has been shown that the curve obtained by plotting the concentration of blood glucose against time approximates to a simple exponential form, ${ }^{45}$ although this relationship may only apply to a limited part of the curve.47 Recently it has been suggested that removal of blood glucose occurs in two phases, and that " the changes in blood glucose have the characteristics of a double exponential function of time: one connected with the equilibration of glucose in the extracellular fluid, and the other with the removal of glucose by the cells.' 61 Opinions vary very much regarding the time taken for equilibration, and the exponential relationship of the subsequent part of the curve, which is considered to represent the disposal of glucose by the body.

Mathematical analysis of the data provided by the intravenous tolerance test have been based on two mutually exclusive physiological concepts. It has been assumed that the glucose disposal, measured by the rate of fall of blood glucose concentration, is related to the total blood glucose level, 8, 19, 85 and that it is related to the 'excess' blood glucose level, i.e. to the difference between the total blood glucose level and the previous fasting value. $4,26,57,87,113$

Apparently valid evidence exists in support of each of these concepts. If, in fact, glucose disposal is related to total blood glucose level, then the total index should not change with variation, either in the loading dose or in the fasting blood glucose level, but an increase has, in fact, been shown to result from both.4, 5, 15, 26, 63 On the other hand, use of the ' excess' blood glucose values involves the assumption that the "fasting blood glucose is a constant baseline during the rapid intravenous glucose tolerance test.'4 There is, however, much evidence that in normal animals, at least, the hepatic output of glucose ceases almost immediately following the administration of intravenous glucose, $105,114,118$ and that this is an important factor in determining the characteristic fall of the blood glucose curve after administered glucose in the intact animal. When the blood glucose level is decreased below the fasting value, the liberation of glucose by the liver is resumed, and the rate of fall ceases to be exponential. ${ }^{26}$

It has been pointed out that 'the difference between the two views may arise from different assumptions concerning the time needed for injected glucose to diffuse through the glucose space.'103 Although Duncan ${ }^{26}$ noted that " there is a variable interval between the injection of glucose and the establishment of an exponential relationship between the fall in blood glucose and time,' he considered that it was generally complete in IO-I 5 minutes. Ikkos and $\mathrm{Luft}^{61}$ claim, however, that diffusion is an important distorting factor for 25-30 minutes from the beginning of the injection.

Pryce ${ }^{103}$ has calculated regression coefficients for $\log$ mean values of Duncan's, ${ }^{26}$ and Baird and Duncan's ${ }^{5}$ data after 27 minutes from the start of the injection, and has stated that in his view there is considerable doubt as to whether a significant increase in the total index occurred with the larger glucose load: and that the reduction in the fasting blood glucose level as a result of treatment with carbutamide was accompanied by a significant increase in both the increment and the total index.

Several other groups of workers have demonstrated that diabetics treated with sulphonylurea compounds show improved glucose tolerance if the data are interpreted in terms of the total index, ${ }^{6,15,66}$ but no change in tolerance if the increment index is used. ${ }^{15,63}$ However, the evidence seems conclusive on other counts that glucose assimilation is not improved by carbutamide, ${ }^{27}$ which suggests that the increment index is a more accurate measure of glucose assimilation.

The rates of disappearance from the blood of various sugars administered intravenously have been related to their chemical structure. The value for the 'increment index' for glucose agrees well with that which would have been expected from its chemical structure, whereas the "total index' value is too low. ${ }^{184}$

The same factors may not be responsible for the changes in blood glucose concentration in normal and diabetic subjects-at least not quantitatively, e.g. the liberation of glucose by the liver may be less influenced by a single injection of glucose in some diabetic patients, and urinary loss is greater than in normal subjects and varies widely. 'Diabetic subjects do not, however, differ from non-diabetic ones with regard to the size of the true volume of distribution of glucose. ${ }^{\prime 61}$ It is possible that different mathematical equations should be applied to diabetic and non' 
diabetic patients if a true index of glucose assimilation, as distinct from glucose tolerance, is desired.

Probably none of the methods used at the moment to interpret and evaluate the rapid intravenous tolerance test are entirely satisfactory. ${ }^{17}$ No further advance can be made in this respect until a routine method is available which can differentiate between glucose movement in and out of the glucose 'pool,' i.e. until it can be determined what exactly is being measured at different times in the course of the test.

In addition, it is likely that the intravenous introduction of glucose into the body is less physiological than is its absorption into the portal system. There is some evidence that glucose tolerance may be less following intravenous glucose than following oral glucose, ${ }^{19,22,85}$ and that the role of the liver and peripheral tissues may be quantitatively different in the two circumstances. 48, 49, 115 It has also been shown that the Staub-Traugott phenomenon does not occur if the two glucose doses are given intravenously. However, if glucose is given by mouth between the first and second intravenous glucose tolerance test, the second curve will be steeper than the first one. ${ }^{19}$

\section{Application of the Rapid Intravenous Test}

The rate of disappearance of intravenously administered glucose-whether the results are analysed on the basis of total or increment blood glucose concentration-gives a good differentiation between the normal and diabetic group. There is very little overlap, and thus the borderline group may be distinguished more accurately. The tests are reproducible, and there is a wide measure of agreement between various groups of workers as regards the values for normal people.

\begin{tabular}{|c|c|c|c|c|}
\hline Author & $\begin{array}{l}\text { Total } \\
\text { Index } \\
\text { (mean) }\end{array}$ & S.D. & $\begin{array}{l}\text { Incre- } \\
\text { ment } \\
\text { Index } \\
\text { (mean) }\end{array}$ & S.D. \\
\hline Lozner et al., r941 & 1.96 & 0.30 & 3.57 & 0.37 \\
\hline $\begin{array}{c}\text { Amatuzio et al., } \\
1953\end{array}$ & 1.34 & 0.27 & 3.71 & 0.40 \\
\hline $\begin{array}{c}\text { Bastenie et al., } \\
1953,1954\end{array}$ & 1.54 & 0.17 & - & - \\
\hline Duncan, 1956 & 1.37 & 0.22 & 3.68 & 0.40 \\
\hline
\end{tabular}

Provided adequate control groups are used, and the tests performed under rigidly standardized conditions (particularly with regard to previous diet), intravenous tests may be valid in detecting alterations in glucose tolerance. Like other glucose tolerance tests, however, the intravenous test in no way distinguishes between blood glucose flow in and out of the 'glucose pool'; it may miss abnormalities in glucose tolerance altogether if two antagonistic processes are simultaneously deficient, $\stackrel{\vec{P}}{\rightarrow}$ e.g. in the Houssay animal; where it does detect $\bar{C}$ an abnormality, it gives little information per se about the mechanism or site of the defect, and may only indicate the need for further investigation. In certain circumstances it may give more useful information in conjunction with administered insulin, ${ }^{130}$ cortisone ${ }^{26}$ or with other simultaneous estimations such as serum inorganic phosphate, plasma citric acid, lactic acid, $\alpha$-ketoglutaric acid, etc., ${ }^{48,49}$ or, after special dietary preparation, in the diagnosis of hypoglycaemic states. ${ }^{20}$

Using intravenous tests decreased glucose tolerance has been demonstrated in cancer, ${ }^{88}$ increasing age, ${ }^{116}$ hepatic disease, ${ }^{2,120,131}$ inflammation, ${ }^{2,128}$ uraemia, $^{2,101}$ fever, ${ }^{25,128}$ obesity, ${ }^{4}$ after the administration of epinephrine ${ }^{3}$ or the stress of surgical operations. ${ }^{25}$

In normal pregnancy intravenous glucose tolerance is normal or even increased. ${ }^{69}$

In hyperthyroidism the intravenous glucose tolerance is usually high or normal, and only vere . occasionally low. ${ }^{3,42,79,86}$

In Addison's disease intravenous glucose toler? ance is very high.?

In Cushing's syndrome it is usually impaired but may be normal of even high. ${ }^{42,131}$

In acromegaly there is no consistent pattern. ${ }^{42}$

\section{The Use of Glucose Tolerance Tests}

The oral glucose tolerance test may be used usefully under three circumstances: (a) in the diagnosis of established diabetes mellitus; (b) in the differentiation of pancreatic from idiopathic steatorrhoea; (c) possibly in the investigation of a case of spontaneous hypoglycaemia. ${ }^{20}$ The overlap which occurs with the oral test between normal and diabetic groups makes the intravenous test preferable for the detection of latent diabetes, and since the intravenous test gives reproducible results it is the test of choice for comparative studies.

The important principles to be observed in $N$ using the glucose tolerance test, whether oral or $\underset{\omega}{\mathrm{W}}$ intravenous, are that each worker should use one $\sigma_{-}$ test consistently, and thus gain experience in 0 interpreting the data from it, and that the conditions of the test should be standardized.

\section{REFERENCES}

1. ALTHAUSEN, T. L. (1940), ₹. Amer. med. Ass., 115, 10i. 2. AMATUZIO, D. S., RAMES, E. D., and NESBITT, S. (1956), F. Lab. clin. Med., 48, 7 I4. 
3. AMATUZIO, D. S., SCHULTZ, A. L., VANDERBILT, M. J., RAMES, E.'D., and NESBITT,'s. (1954), $\not$. clin. Invest., 33, 97.

4. AMATUZIO, D. S., STUTZMAN, F. I., VANDERBILT, J. M., NESBITT, S. (1953), Ibid., 32, 428.

5. BAIRD, J. D., and DUNCAN, L. J. P. (1957), Clin. Sci., I, I47.

6. BASTENIE, P. A., FRANKSON, J. R. M., DEMANET, T. C., DE MUETTER, R., and CONARD, V. (1957), Lancet, i, 504 .

7. BASTENIE, P. A., CONARD, V., and FRANKSON, J. R. M. (1954), Diabetes, 3, 205.

8. BASTENIE, P. A., CONARD, V., FRANKSON, J. R. M., KESTENS, J., and KOVAKS, L. (1953), Arch. int. Pharmacodyn., 93, 277.

9. BEELER, C., BRYAN, A., CATHCART, E. P., and FITZ, R. (1922), Э. metab. Res., $1,549$.

ro. BERNARD, C. (1853), 'Nouvelle fonction de foie,' Baillière, Paris.

11. BLOTNER, H. (1945), Arch. intern. Med., 75, 39.

12. BLUMENTHAL, F. (1905), Beitr. chem. Physiol. Path., 6, 329.

13. BOCK, J. C., SCHNEIDER, H., and GILBERT, M. (1926), ¥. biol. Chem., 69, 9 .

14. BOWMAN, K. M., WORTIS, J., ORENSTEIN, L. L., and GOLDFARB, W. (1939), Proc. Soc. exp. Biol. (N.Y.), 42, 37.

I5. BUTTERFIELD, W. J. H., CAMP, J. L., HARDWICK, C., and HOLLING, H. E. (1948), Lancet i, 753 .

16. CAJORI, F. A., CROUTER, C. Y., and PEMBERTON, R. (I925), $\mathcal{F}$. biol. Chem., 66, 89.

17. CATILLO, S. (1957), La Pediatria (Napoli), 65, 809.

18. COMESATTI, G. (1907), Beitr. chem. Physiol. Path., 9, 67.

19. CONARD, V. (1955), Acta gastro-ent. belg., 18 (7-8), 655.

20. CONN, J. W., and SELTZER, H. J. (1955), Amer. F. Med., I9, 460 .

21. CONN, J. W. (1940), Amer. F. med. Sci., 199, 555.

22. CORI, C. F. (1925), f. biol. Chem., 66, 691.

23. CRAWFORD, T. (1940), Arch. Dis. Childh., 15, 184.

24. DAVIDSON, E. C., and ALLEN, C. I. (1925), Bull. Fohns Hopk. Hosp., 37, 217.

25. DRUCKER, W. R., MILLER, M., ABBOTT, W. E., CRAIG, J. W., JEFFERIES, W. MCK., LEVEY, S., and WOODWARD, H. (1952), Abstract of Proceedings of Central Society for Clinical Research, $\mathcal{F}$. Lab. clin. Med., 40, 794 .

26. DUNCAN, L. J. P. (1956), Quart. F. exp. Physiol., 41, 85 and 453.

27. DUNCAN, L. J. P., and BAIRD, J. D. (1959), Pharmacol. Rev. (in the press).

28. DU VIGNEAUD, V., and KARR, W. G. (1925), F. biol. Chem., 66, 281.

29. EVENSON, O. K. (1942), Acta med. scand., Suppl. 126, 1 ro.

30. EXTON, W. G., and ROSE, A. R. (1934), Amer. F. clin. Path., 4,381 .

31. FAJANS, S. S., and CONN, J. W. (1954), Diabetes, 3, 296.

32. FAIRLEY, N. H. (1936), Trans. roy. Soc. trop. Med. Hyg. 30, 9.

33. FENTON, P. F. (1945), Amer. F. Physiol., 144, 609.

34. FOSTER, R. A., and FRANCIS, B. G. (1955), Brit. $\mathcal{f}$. Anaesth., 27, 291.

35. FRAZER, A. C., FRENCH, I. M., THOMAS, G., and THOMPSON, M. D. (1952), Clin. Sci., II, 141.

36. FREEDMAN, P., MOULTON, R., ROSENEHEIM, M. L. SPENCER, A.' G., and WILLÖUGHBY, D. A.' (1958), Quart. F. Med., 27 (107), 307.

37. FREEMAN, H., RODNICK, E. H., SHAKOW, D., and LEBEAUX, 'T.' (1944), Psychosom. Med., 6, $31 \mathrm{I}$.

38. GADDIE, R., THOMAS, G., SMITH, N., and FRENCH, J. M. (1957), Quart. F. Med., 26 (50), 121.

39. GILBERT, M., SCHNEIDER, H., and BOCK, J. C. (1926), f. biol. Chem., 67, 629 .

40. GILBERT, J. A. L., and DUNLOP, D. M. (1947), Brit. med. F., ii, 330 .

41. GLASSBERG, B. Y. (1930), Arch. intern. Med., 46, 984.

42. GOLDBERG, L., and LUFT, R. (1949), Acta med. scand., 135, 1 .

43. GOLDBLATT, M. W. (1925), Biochem. F., 19, 948.

44. GRAHAM, J. B. (1951), Surg. Gynec. Obstet., 92, 105.

45. GREVILLE, G. D. (1943), Biochem. F., 37, 17.

46. HALE-WHITE, R., and PAYNE, W. W. (1926), Quart. $\mathcal{F}$. Med., 19, 393.

47. HAMILTON, B., and STEIN, A. F. (1942), f. Lab. clin. Med., 27, 491.
48. HENNEMAN, D. H., ALTSCHULE, M. D., and GONCZ, R. M. (1954), Arch. intern. Med., 94, 402.

49. HENNEMAN, D. H. ALTSCHULE, M. D., GONCZ R. M., and ALEXANDER, L. (1954), Arch. Neurol. Psychist., $72,688$.

50. HERRICK, W. W. (1923), Э. Amer. med. Ass., 81, 1942.

51. HIMSWORTH, H. P. (1932), Lancet, 11, 935.

52. HIMSWORTH, H. P. (1933), Clin. Sci., 34 (i), 1.

53. HIMSWORTH, H. P. (1934), Brit. med. $\mathcal{f}$., ii, 57.

54. HIMSWORTH, H. P. (1934), F. Physiol. (Lond.), 81, 29.

55. HINKLE, L. E., and WOLF, S. (1952), Diabetes, $1,383$.

56. HLAD, C. J., Jr., ELRICK, H., and WITTEN, T. A. (1956), f. clin. Invest., 35, 1139.

57. HOENIG, V. (rgo6), Cas. Lek. ces., 95, ror 5.

58. HORVATH, S. M., WISOTSKY, R., and CORWIN, W. (1947), F. Geront., 2, 25.

59. HOSTERS, H. (1932), Z. ges. exp. Med., 83, 72.

60. HUNTER, R. A., and GREENBERG, H. P. (1954), Lancet, ii, 58.

6r. IKKOS, D., and LUFT, R. (1957), Acta endocr. (Kbh.), 25, 312 and 335 .

62. INGLE, D. J. (1954), f. clin. Endocr., 10, 1312.

63. INTROZZI, P., and MARIGO, S. (1958), Minerva med. (Torino), 49, 1492.

64. IRVING, E. M., and WANG. I, (1954), Glasgow med. F., 35,275 .

65. JACKSON, W. P. U. (1952), Brit. med. F., 2, 690.

66. JENSEN, S. E., LUNDBAEK, K., MOLLER, B., and RAFAELSEN, O. J. (1958), Acta med. scand., 160, 67 .

67. JOHN, H. J. (1934), Endocrinology, 18, 75.

68. JOHN, H. J. (1939), ₹. Pediat., 14, 737.

69. JOHNSTON, D. G., and BONSNES, R. W. (1948), f. clin. Invest., 27, 745 .

70. JOKIPPI, S. G., and TURPEINEN, O. (1954), Ibid., 33, 452, 71. JORGENSEN, S. (1926), Acta med. scand., 65, 116.

72. LANGER, P. H., Jr., ROMANSKY, M. J., and ROBIN, E. D. (I946), Amer. $¥$. med. Sci., 212, 466 .

73. LAURENCE, R. D., and BUCKLEY, O. B. (1927), Brit. F. exp. Path., 8, 58.

74. LEONARDS, J. R., and FREE, A. H. (1945), Ұ. Lab. clin. Med., 30, 1070.

75. LENNOX, W. G. (1927), Arch. intern. Med., 40, 182.

76. LENNOX, W. G., and BELLINGER, M. (1927), Ұ. clin. Invest., $\mathrm{xl}, 33 \mathrm{I}$.

77. LOEB, O., and STADLER, H. (1914), Arch. exp. Path. Pharmak., 77, 326

78. LOUGHLIN, W. C., MOSENTHAL, H. O., HALPERN, R. (1943), F. Lab. clin. Med., 28, 1165.

79. LOZNER, E. L., WINKLER, A. N., TAYLOR, F. H. L., and J. P. PETERS (I94I), F. clin. Invest., 20, 507.

80. LUND, C. J., and WEESE, W. H. (r953), Amer. F. Obstet. Gynec., 65, 815.

81. MCLELLAN, W. S., and WARDLAW, S. H. (1932), $\mathcal{F}$. clin. Invest., II, 513 .

82. MACGREGOR, G. A., and SHAPER, A. G. (1957), Brit. med. F., $\mathrm{i}, 917$.

83. MCCULLAGH, E. P., and JOHNSTON, C. R. K. (1938), Amer. F. med. Sci., 195, 773.

84. MACKAY, E. M., and BERGMAN, H. C. (1933), f. biol. Chem., I01, 453.

85. MACHO, L., and LICKO, V. (1957), Experientia (Basel), $13 / 5,204$.

86. MACHO, L. (1958), Acta med. scand., 160, 485.

87. MACKLER, B., LICHTENSTEIN, H., and GUEST, G. M. (1952), Amer. F. Physiol., 168, 126.

88. MARKS, P. A., and BISHOP, J. J. (1957), $\mathcal{~ f . ~ c l i n . ~ I n v e s t . ~}$ 36, 254.

89. MERRIVALE, W. H. H., and HUNTER, R. A. (1954), Lancet, ii, 939.

90. MIRSKY, I. A., discussion of a paper by Sevringhaus, E. L. (1944), Proc. Amer. Diabetes, Ass., 4, 121.

91. MIRSKY, I. A. (1946), Proc. cent. Soc. clin. Res., 19, 74.

92. MOEHLIG, R. C., and ABBOTT, H. L. (1947), F. Amer. med. Ass., 134, 1521.

93. MOSENTHAL, H. O., and BARRY, E. (1946), Amer. F. dig., Dis., 13, 160.

94. MOSENTHAL, H. O., and BARRY, E. (1950), Ann. intern. Med., 33, 1175 .

95. MOYER, J. H., and WOMACK, C. R. (1950), Amer. F. med. Sci., 219, 16r. 96. MYERS, G. B., and MCKEAN, R. M. (1935), Amer. F. clin.
Path., 5, 299.

97. NIELSEN, O. J. (1928), Biochem. F., 22, 1490. 
98. NISELL, O. (1957), Acta med. scand., 157, 445.

99. OGILVIE, R. F. (1935), Quart. F. Med., 28, 244.

roo. PEMBERTON, R., and FOSTER, G. L. (1920), Arch. intern. Med., 25, 243.

IOI. PERKOFF, G. T., THOMAS, C. L., NEWTON, J. D. SELIMAN, J. C., and TYLER, F. H. (1958), Diabetes, 7, 375 .

102. PIJOAN, M., and GIBSON, J. G. (1938), Amer. F. Physiol., 121,534 .

103. PRYCE, I. G. (1958), Lancet, i, 645.

104. QUIGLEY, J. P., and PHELPS, K. R. (1934), Amer. $\mathcal{F}$. Physiol., 109, 133.

105. REICHARD, G. A., FRIEDMANN, B., MAAS, A. R., and WEINHOUSE, S. (1958), $\mathcal{F}$. biol. Chem., 230, 387 .

106. REID, J., MACDOUGALL, A. I., and ANDREWS, M. M. (1957), Brit. med. F., 2, 1071.

107. REYNELL, P. C., and SPRAY, G. H. (1956), f. Physiol. (Lond.), 134, 531.

108. REYNELL, P. C., and SPRAY, G. H. (1956), Ibid., 131, 452 ro9. ROSS, C. W. (1938), Arch. dis. Childh., 13, 289.

r 10. RUSSELL, J. A. (1938), Amer. F. Physiol., 122, 547

I I 1. SANDLER, B. P. (1940), Rev. Gastroent., 7, 485.

I12. SCHERF, D. (1933), Wien. klin. Wschr., 46, 69.

1 13. SCOW, R. O., and CORNFIELD, J. (1954), Amer. F. Physiol., I79, 39.

114. SEARLE, G. L., and CHAIKOFF, I. L. (1952), Ibid., 170, 456.

115. SHRIFTER, N., and KRITZER, M. D. (1956), Arch. intern. Med., 98, 28.

116. SILVERSTONE, F. A., BRAND FONBRENER, M., SHOCK, N. W., and ÝIENGST, M. J. (1957), $\mathscr{F}$. clin. Invest., 36, 504 .

1 7. SOISALO, P. (1929-30), Acta med. scand., Suppl. 34-35, 184.
118. SOSKIN, S., ESSEX, H. E., HERRICK, J. F., MANN, F. C. (1938), Amer. F. Physiol., 124, 558.

I19. SOSKIN, S., ALLWEISS, M. D., and COHN, D. J. (1934), Ibid., 109, 155.

120. SOSKIN, S. (1944), f. clin. Endocr., 4, 75.

121. SOSKIN, S. (1951), Postgrad. Med.; 10, 108.

122. SRINIVASAN, M. (1957), Lancet, ii, 317.

123. SWEENEY, J. S., MUIRHEAD, J. J., and ALLDAY, L. E. (1937), Amer. F. clin. Path., 7, 482.

124. SWEENEY, J. S., and LACKEY, R. W. (1928), Arch. intern. Med., 4I, 257.

125. TAYLOR, R. M., and WIGHTMAN, K. J. R. (1952), Amer. f. med. Sci., 224, 190 .

126. THOMPSON, R. H. S., and KING, G. J. (1957), 'Biochemical Disorders in Human Disease,' p. 512.

127. TOLSTOI, E. (1929), f. biol. Chem., 83, 747.

128. TUNBRIDGE, E. R., and ALLIBONE, E. C. (1940), Quart. है 7. Med., 9, II.

129. UNGER, R. H. (1957), Ann. intern. Med., 47, I 138.

130. VOLK, B. W., and LAZARUS, S. S., and LEW, H. (1953), Metabolism, 4, 10.

I3I. WALLER, J. J., STRIBLING, S. H., and SPURR, C. L. (1955), Clin. Res. Proc., 3, 15.

132. WAYBURN, E., and GRAY, H. (1942), Am. F. Med. Sci., 204, 823 .

133. WILLIAMS, R. H. (1955), 'Textbook of Endocrinology.' W. B. Saunders, Philadelphia and London.

134. WYNGAARDEN, J. B., STANTON, S., and FOLEY, J. B. (1957), f. clin. Invest., 36, 1395.

135. WEISS, T. E., SEGALOFF, A., and MOORE, C. (1957), Metabolism, 6, 103.

136. ZOLLINGER, R. M., and HOERR, S. O. (1947), f. Amer. med. Ass., 134, 575 .

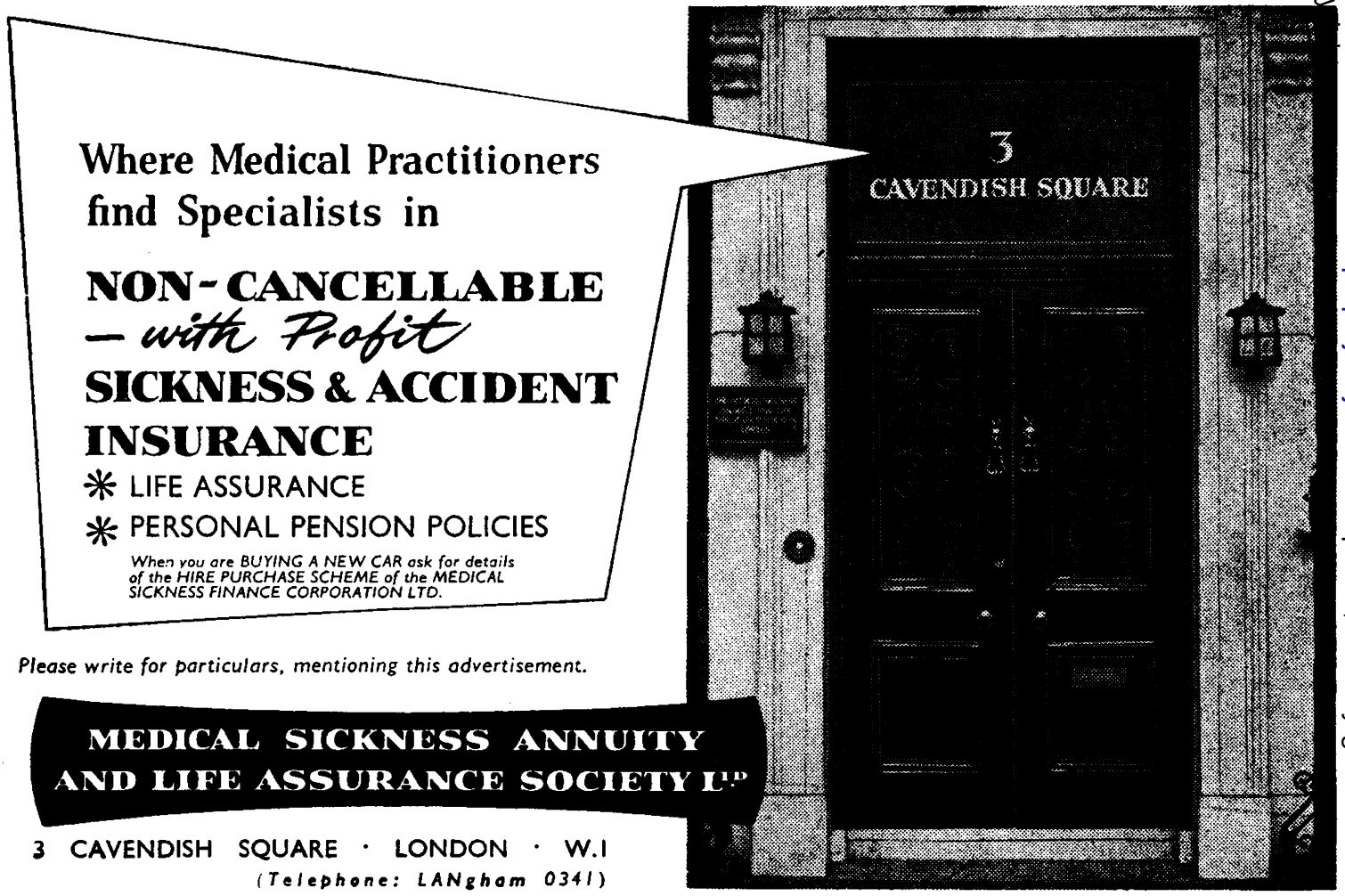

